\title{
Making sense of the Global Coronavirus Data: The role of testing rates in understanding the pandemic and our exit strategy
}

\section{ANALYSES FROM ACALM STUDY UNIT}

\author{
Dr Rahul Potluri \\ Dr Deepthi Lavu
}

\section{ACALM STUDY UNIT}

Correspondence to: Dr Rahul Potluri, Founder ACALM Study Unit. Email: rahulpotluri@outlook.com

Conflict of interest statement: No relevant conflicts of interest to declare. No relevant disclosures. 
medRxiv preprint doi: https://doi.org/10.1101/2020.04.06.20054239; this version posted April 11, 2020. The copyright holder for this preprint (which was not certified by peer review) is the author/funder, who has granted medRxiv a license to display the preprint in perpetuity.

It is made available under a CC-BY 4.0 International license .

\begin{abstract}
The Coronavirus disease 2019(COVID-19) outbreak has caused havoc across the world. Subsequently, research on COVID-19 has focused on number of cases and deaths and predicted projections have focused on these parameters. We propose that the number of tests performed is a very important denominator in understanding the COVID-19 data. We analysed the number of diagnostic tests performed in proportion to the number of cases and subsequently deaths across different countries and projected pandemic outcomes.
\end{abstract}

We obtained real time COVID-19 data from the reference website Worldometer at 0900 BST on Saturday $4^{\text {th }}$ April, 2020 and collated the information obtained on the top 50 countries with the highest number of COVID 19 cases. We analysed this data according to the number of tests performed as the main denominator. Country wise population level pandemic projections were extrapolated utilising three models - 1) inherent case per test and death per test rates at the time of obtaining the data (4/4/2020 0900 BST) for each country; 2 ) rates adjusted according to the countries who conducted at least 100000 tests and 3) rates adjusted according to South Korea.

We showed that testing rates impact on the number of cases and deaths and ultimately on future projections for the pandemic across different countries. We found that countries with the highest testing rates per population have the lowest death rates and give us an early indication of an eventual COVID-19 mortality rate. It is only by continued testing on a large scale that will enable us to know if the increasing number of patients who are seriously unwell in hospitals across the world are the tip of the iceberg or not. Accordingly, obtaining this information through a rapid increase in testing globally is the only way which will enable us to exit the COVID-19 pandemic and reduce economic and social instability. 
medRxiv preprint doi: https://doi.org/10.1101/2020.04.06.20054239; this version posted April 11, 2020. The copyright holder for this preprint (which was not certified by peer review) is the author/funder, who has granted medRxiv a license to display the preprint in perpetuity.

It is made available under a CC-BY 4.0 International license .

\section{Introduction}

The Coronavirus disease 2019(COVID-19) outbreak has caused havoc across the world after it was first reported in Wuhan, China ${ }^{1,2}$. Subsequently, research on COVID-19 has exploded to understand the new disease and its impact on mankind ${ }^{3-16}$. However, the number of baseless articles resulting in fake news articles has also gone up exponentially ${ }^{17-19}$. A number of models have been adapted by policymakers to predict the course of COVID-19 across the world ${ }^{4,6,13,20}$. The reason for such models is to ensure that healthcare systems can plan services to help them cope with the demands of this new disease which is resulting in serious cases leading to hospitalisation ${ }^{3,8}$. Core elements of the prediction models have been the number of cases and deaths reported and these studies extrapolated the numbers forward to the population over time ${ }^{4,6,13,20}$. Given the pandemic course of COVID-19, it has become common practice to compare its spread in different countries using case fatality rates ${ }^{3,4,7,13}$. However, such methods only tell us part of the story. Vast differences amongst countries in their testing policies for varied reasons including availability of testing equipment, infrastructure, resources and local governing policies affect case fatality rates. In addition, comparing case fatality rates between countries which are at different stages of the epidemic in their region would be erroneous as rates at the beginning and end would be lower compared to rates at the peak when healthcare services are stretched to their limits. Therefore, the search for a common yardstick or denominator is necessary to compare different countries so that the data can be extrapolated for global comparison. Over the past four weeks, as COVID-19 spread further around the world, testing rates have picked up in most countries. We propose that analysis of the number of diagnostic tests performed in proportion to the number of cases and subsequently deaths in the underlying populations of different countries is the best way to predict what might happen next. We analysed this from the ACALM Big Data research unit. 
medRxiv preprint doi: https://doi.org/10.1101/2020.04.06.20054239; this version posted April 11, 2020. The copyright holder for this preprint (which was not certified by peer review) is the author/funder, who has granted medRxiv a license to display the preprint in perpetuity.

It is made available under a CC-BY 4.0 International license .

\section{Methods}

We obtained real time COVID-19 data from the reference website Worldometer at 0900 BST on Saturday $4^{\text {th }}$ April, 2020 and collated the information obtained on the top 50 countries with the highest number of COVID-19 cases $^{21}$. From this source, we obtained many parameters including the number of country wise COVID-19 cases, deaths, tests performed, cases per million population, deaths per million population and tests per million population. China and Saudi Arabia were excluded due to lack of data on number of diagnostic tests performed, therefore numbers 51 and 52 were included in the compiled top 50 list.

We obtained case fatality rates by dividing the number of deaths by the number of cases represented as a percentage. Next, tests per positive case were calculated by dividing the number of tests by the number of cases. We then calculated the number of cases per test and number of deaths per test by dividing the number of cases and deaths respectively, by the number of tests represented as a percentage (a case per test rate and a death per test rate). Subsequently, we obtained the population of these countries (in millions) from the number of cases divided by the number of cases per million. We can obviously obtain more accurate country population statistics from other sources but to maintain our consistency of the data source and methodology (for all countries), we derived the information from this data only. We then analysed the above in three steps.

Firstly, we extrapolated the population level pandemic data for each country in terms of cases and number of deaths according to each country's case per test rate and death per test rate as calculated as a snapshot at the time of obtaining the data.

There are a number of limitations to the methodology used when taking a snapshot of these countries at a point in time, as done above, especially because each country is likely to be on a different part of the pandemic curve and extrapolating to the population level data is not likely to be 
medRxiv preprint doi: https://doi.org/10.1101/2020.04.06.20054239; this version posted April 11, 2020. The copyright holder for this preprint (which was not certified by peer review) is the author/funder, who has granted medRxiv a license to display the preprint in perpetuity.

It is made available under a CC-BY 4.0 International license .

accurate. Therefore, we further undertook a consistent adjustment according to countries which performed the most tests; in favour of larger countries with bigger populations we chose an arbitrary cut off of 100,000 tests per country. 15 countries had undertaken more than 100,000 tests and as all these countries showed differences in their cases/test and deaths/test we took the 15 country group as a whole to obtain an adjustment factor according to the cases/test and deaths/test. Using this we derived a case per test rate of $13.53 \%$ and a death per test rate of $0.77 \%$ for the 15 country group. Based on the above numbers, we extrapolated figures at the population level for all 50 countries to calculate the predicated number of cases and deaths.

We felt it necessary to undertake further analysis, the third analysis, to adjust the data to a country which is progressing towards the latter half of the pandemic curve - South Korea ${ }^{22-24}$. Ideally, undertaking this adjustment with data from China would be most appropriate but data for the number of diagnostic tests performed in China was not available. The adjustment factor for South Korea was a case per test rate of $2.23 \%$ and $0.04 \%$ death per test rate.

Hence our country wise population level pandemic projections were based on 1) inherent case per test and death per test rates at the time of obtaining the data (4/4/2020 0900 BST) for each country 2) rates adjusted according to the countries who conducted at least 100000 tests and 3) rates adjusted according to South Korea. Our analyses are shown in the tables and figures. No additional analyses were performed. 
medRxiv preprint doi: https://doi.org/10.1101/2020.04.06.20054239; this version posted April 11, 2020. The copyright holder for this preprint (which was not certified by peer review) is the author/funder, who has granted medRxiv a license to display the preprint in perpetuity.

It is made available under a CC-BY 4.0 International license.

\section{Results}

Full data obtained on 4/4/2020 are shown in Table 1 for the top 50 countries with highest number of COVID-19 cases in the world. Table 2 shows the countries according to number of tests performed per positive diagnosed COVID-19 cases. Table 3 shows population level pandemic projections for cases and deaths according to each individual country's case per test and death per test rate on 4/4/2020 0900 BST. Table 4 shows population level pandemic projections adjusted for the combined case per test and death per test rate of the 15 countries group that have performed at least 100000 tests. Table 5 shows the population level pandemic projections adjusted for the case per test and death per test rate of South Korea. Figure 1 show a scatter plot to show the relationship between the case fatality rate and the testing rate as a percentage of the total population of the country for the countries which have tested at least $1 \%$ of their total population. Italy was excluded from this scatter plot as it was an outlier with a case fatality rate of $12.25 \%$. 
medRxiv preprint doi: https://doi.org/10.1101/2020.04.06.20054239; this version posted April 11, 2020. The copyright holder for this preprint (which was not certified by peer review) is the author/funder, who has granted medRxiv a license to display the preprint in perpetuity.

It is made available under a CC-BY 4.0 International license .

\section{Discussion}

COVID-19 statistics are complex and comparing different countries based on number of total cases, deaths and/or case fatality rate does not show the complete picture (Table 1). A common denominator is required to make senses of these numbers and we propose that this denominator is the number of diagnostic tests performed. In our analyses we showed the deaths and cases in relation to the number of tests performed and presented population level pandemic projections based on these. This is particularly relevant in the current environment where testing parameters vary across different countries leading to non-uniformity in projections. It is important to discuss each of our different analyses in turn, the rationale, drawbacks and what it means for different countries.

As table 2 shows, the number of tests per positive case is an important parameter because it is an indication of how widely the testing policy of the respective country has followed the advice from the World Health Organisation (WHO) ${ }^{1}$. Analysis using tests per positive case approach favours richer countries with smaller populations such as the UAE which tests over 174 people per positive case. However, there are exceptions to this such as Russia and India which both have large populations. This data suggests that both countries are undertaking a large number of tests to detect one positive case. In these countries the overall percentage of population tested is low. Bias in these figures could be the reliability of the reported number of tests performed. For example, the figures for India as released by the Indian Council of Medical Research ${ }^{25}$ in terms of numbers tested are not as high as the raw data obtain from this source but for consistency in dealing with all the raw data in the same way, we analysed according to the data obtained from Worldometer. Of course similar bias could be inherent for the testing data for all countries but in our defence we have treated all the raw data obtained in the same way for consistency and have opened up the data for scrutiny. Another important factor to consider here is the testing policy followed in these countries. Are the countries at the top of this table testing a cohort of people who have a low possibility of carrying this 
medRxiv preprint doi: https://doi.org/10.1101/2020.04.06.20054239; this version posted April 11, 2020. The copyright holder for this preprint (which was not certified by peer review) is the author/funder, who has granted medRxiv a license to display the preprint in perpetuity.

It is made available under a CC-BY 4.0 International license .

infection? If only those with symptoms are tested then individuals are more likely to test positive for COVID-19 leading to a low test per positive number. If these countries test the sickest of patients as you would expect in countries with the largest populations and limited testing kits to do, then high testing rates per positive case is even more remarkable as it may suggest lower virus rates compared to other countries but this cannot be concluded from this study. Furthermore, the reliability of local testing kits is an important factor as there are a number of reports of COVID-19 patients testing negative numerous times before a positive test ${ }^{11}$. South Korea can be considered as an exception to this because following an explosion of cases initially, they embarked on an extensive testing policy along with isolation policies combined with the utility of mobile tech and applications to inform the public about real time locations of positive cases. As such, it is widely accepted that South Korea are further along the pandemic curve and the rates of new cases and deaths have significantly reduced $22-24$.

Projections for the pandemic on an individual population level are very important for governments to plan and organise healthcare systems in response. COVID-19 presents a unique problem because there is no immunity for this in the community, nor a vaccination or targeted medical treatment. Given that this is a highly contagious disease that spreads very quickly, if a large part of the population suffer from the disease in a short space of time, even if majority of cases are mild, a small minority of severe/critical cases will still lead to significant pressures on healthcare systems as now seen in Italy, Spain and the USA (particularly New York). Globally lockdowns have been instated to reduce the spread of infection, allow the healthcare systems to cope with the condition and "flatten the curve" of the pandemic. These were not enforced all at once and the projections in table 3 are based on the data available on 4/4/2020 and a snapshot depending on the actions, policies of individual countries. Much more complex models have been undertaken by different groups which included time as a variable ${ }^{20}$. However, we propose that testing rate is a very important parameter in projecting the outcomes of the pandemic. Therefore, whilst it seems far-fetched to suggest that Indonesia may end up with over 7 million deaths from less than 2000 cases reported so far, we have 
medRxiv preprint doi: https://doi.org/10.1101/2020.04.06.20054239; this version posted April 11, 2020. The copyright holder for this preprint (which was not certified by peer review) is the author/funder, who has granted medRxiv a license to display the preprint in perpetuity.

It is made available under a CC-BY 4.0 International license .

to note that only just over 7000 tests have been performed for a country of 283 million. There are a number of factors for low testing rates such as local policies, lack of resources and equipment and it is impossible to discuss them all; we point out that testing rates are extremely important in projecting the outcomes of the pandemic particularly in countries with large populations. In this context, if we look at countries such as the UK and India both of which have tested over 100000 tests, given the large populations and their case per test rate and death per test rate on $4 / 4 / 2020$, both countries have projections for over 1000000 deaths.

As mentioned the position of any given country on the pandemic curve is important in determining population level projections and since we proposed that testing rates have an impact on projections we adjusted all projections to the combined case per test and death per test rates of all the countries that have performed over 100000 tests. This analyses is shown in table 4 . We also felt that projections should be done on the case per test and death per test rate for South Korea given the countries position on the pandemic curve and are shown in table $4^{22-24}$. Both these analyses are biased in terms of predications for total deaths for countries with larger populations. For example in spite of the case per test and deaths per test rate being low in India, as the population of the country is large, the projections are still over 10 millions deaths as per table 4 (adjustment according to countries which have performed more than 100,000 tests) and 500,000 deaths as per table 5 (South Korea adjustment).

It is also no coincidence that none of the top 10 countries in table 4 or table 5 have tested at least $1 \%$ of the total population. We looked at the countries that have tested at least $1 \%$ of their populations and looked at their cases fatality rate. We excluded the $10^{\text {th }}$ country on the list - Italy because of its high case fatality rate of $12.25 \%$. All other countries had a case fatality rate of $3 \%$ or lower. We then correlated the case fatality rate with percentage of the population tested as shown in figure 1. This approach showed higher percentage of population tested in countries with lower populations who have tested a higher proportion of their total population, but not in all cases. Both 
medRxiv preprint doi: https://doi.org/10.1101/2020.04.06.20054239; this version posted April 11, 2020. The copyright holder for this preprint (which was not certified by peer review) is the author/funder, who has granted medRxiv a license to display the preprint in perpetuity.

It is made available under a CC-BY 4.0 International license .

Germany (population 83 million) and to a lesser extent Australia (population 25million) and have tested more than $1 \%$ of their population and showed low case fatality rates (1.4\% Germany and $0.54 \%$ Australia). Provided that their testing criteria is reliable, these figures may serve as early indicators of the actual mortality rate for COVID-19 and these low figures are encouraging.

None of these methods used for projections are likely to hold true in reality. If we go back to the analyses for South Korea and its projections of approximately 20,000 deaths, there have been only 177 deaths in South Korea so far. It seems highly improbable that for a country where the number of cases and deaths have significantly tailed off would end up with 19,952 deaths. Furthermore, the herd immunity concept has been a strategy to contain disease spread not only for COVID-19 but across a number of pandemics such as Swine Flu ${ }^{26}$. Although it is widely debated as to what percentage of the population would need to be affected by the disease to confer herd immunity, a figure of $60 \%$ has been widely used ${ }^{27-29}$. Even if we adjust the South Korea figures (table 5) to $60 \%$, we will probably still over estimate the number of deaths.

Where does all of this leave us and what is the point of all these statistics and analyses? Clearly from the example of South Korea we can contain COVID-19 and in spite of differences of the specific policies of lockdown between countries, social distancing and limiting spread are the broad themes to take forward. The analyses in this study highlight the importance of testing as the relevant denominator for which all the COVID-19 data should be related to. The testing policy is advocated strongly by the WHO in their COVID-19 statements ${ }^{1}$. The suggested early indication of a low mortality rate from our analyses, coupled with the fact that COVID-19 is a new disease affecting the globe in a short time, it is highly plausible that the serious cases and deaths we are seeing in the some countries may be the tip of the iceberg of a disease that has spread widely. If we look at influenza data there are millions of cases and up to half a million deaths worldwide every year due to flu and these tend to be seasonal in spite of vaccination programmes and herd immunity to some extent ${ }^{27-30}$. In the case of COVID-19 we might be experiencing the full whammy of a disease without 
medRxiv preprint doi: https://doi.org/10.1101/2020.04.06.20054239; this version posted April 11, 2020. The copyright holder for this preprint (which was not certified by peer review) is the author/funder, who has granted medRxiv a license to display the preprint in perpetuity.

It is made available under a CC-BY 4.0 International license .

immunity, globally all at once resulting in deaths. The magnitude of these deaths in perspective to other diseases such as Influenza may not be high ${ }^{30}$. Our analyses in this study do not prove this theory but the only thing that can is continued extensive and rapid testing across the globe. This may be the only exit strategy to prevent COVID-19 related economic and social breakdown. 
medRxiv preprint doi: https://doi.org/10.1101/2020.04.06.20054239; this version posted April 11, 2020. The copyright holder for this preprint (which was not certified by peer review) is the author/funder, who has granted medRxiv a license to display the preprint in perpetuity.

It is made available under a CC-BY 4.0 International license .

\section{References}

1) WHO. Coronavirus disease 2019 (COVID-19) situation report-43.March 3, 2020. https://www.who.int/docs/default-source/coronaviruse/situation-reports/20200303-sitrep43-covid-19.pdf?sfvrsn=2c21c09c_2 (accessed April 4, 2020)

2) Huang C, Wang Y, Li X, Ren L, Zhao J, Hu Y, Zhang L, Fan G, Xu J, Gu X, Cheng Z, Yu T, Xia J, Wei Y, Wu W, Xie X, Yin W, Li H, Liu M, Xiao Y, Gao H, Guo L, Xie J, Wang G, Jiang R, Gao Z, Jin Q, Wang J, Cao B. Clinical features of patients infected with 2019 novel coronavirus in Wuhan, China. Lancet. 2020 Feb 15;395(10223):497-506. doi: 10.1016/S01406736(20)30183-5. Epub 2020 Jan 24.Erratum in: Lancet. 2020 Jan 30;:. PubMed PMID: 31986264.

3) Kinross P, Suetens C, Gomes Dias J, Alexakis L, Wijermans A, Colzani E, Monnet DL, European Centre For Disease Prevention And Control Ecdc Public Health Emergency Team. Rapidly increasing cumulative incidence of coronavirus disease (COVID-19) in the European Union/European Economic Area and the United Kingdom, 1 January to 15 March 2020. Euro Surveill. 2020 Mar;25(11). doi:10.2807/1560-7917.ES.2020.25.11.2000285. Epub 2020 Mar 16. PubMed PMID: $32186277 ;$ PubMed Central PMCID: PMC7096777.

4) Li C, Chen L, Chen X, Zhang M, Pang CP, Chen H. Retrospective analysis of the possibility of predicting the COVID-19 outbreak from Internet searches and social media data, China, 2020. Euro Surveill. 2020 Mar;25(10). doi:10.2807/1560-7917.ES.2020.25.10.2000199. PubMed PMID: 32183935; PubMed Central PMCID: PMC7078825. 
medRxiv preprint doi: https://doi.org/10.1101/2020.04.06.20054239; this version posted April 11, 2020. The copyright holder for this preprint (which was not certified by peer review) is the author/funder, who has granted medRxiv a license to display the preprint in perpetuity.

It is made available under a CC-BY 4.0 International license .

5) Tang B, Xia F, Tang S, Bragazzi NL, Li Q, Sun X, Liang J, Xiao Y, Wu J. The effectiveness of quarantine and isolation determine the trend of the COVID-19 epidemics in the final phase of the current outbreak in China. Int J Infect Dis. 2020 Mar 11. pii: S1201-9712(20)30137-5. doi: 10.1016/j.ijid.2020.03.018. [Epub ahead of print] PubMed PMID: 32171948.

6) Maxmen A. The race to unravel the biggest coronavirus outbreak in the United States. Nature. 2020 Mar;579(7798):181-182. doi: 10.1038/d41586-020-00676-3.PubMed PMID: 32152595.

7) Porcheddu R, Serra C, Kelvin D, Kelvin N, Rubino S. Similarity in Case Fatality Rates (CFR) of COVID-19/SARS-COV-2 in Italy and China. J Infect Dev Ctries. 2020 Feb 29;14(2):125-128. doi: 10.3855/jidc.12600. PubMed PMID:32146445.

8) Ji Y, Ma Z, Peppelenbosch MP, Pan Q. Potential association between COVID-19 mortality and health-care resource availability. Lancet Glob Health. 2020 Apr;8(4):e480. doi: 10.1016/S2214-109X(20)30068-1. Epub 2020 Feb 25. PubMed PMID: 32109372.

9) Xiang YT, Li W, Zhang Q, Jin Y, Rao WW, Zeng LN, Lok GKI, Chow IHI, Cheung T, Hall BJ. Timely research papers about COVID-19 in China. Lancet. 2020 Feb 29;395(10225):684-685. doi: 10.1016/S0140-6736(20)30375-5. Epub 2020 Feb 17. PubMed PMID: 32078803.

10) Cheng ZJ, Shan J. 2019 Novel coronavirus: where we are and what we know. Infection. 2020 Apr;48(2):155-163. doi: 10.1007/s15010-020-01401-y. Epub 2020 Feb 18. Review. PubMed PMID: 32072569. 
medRxiv preprint doi: https://doi.org/10.1101/2020.04.06.20054239; this version posted April 11, 2020. The copyright holder for this preprint (which was not certified by peer review) is the author/funder, who has granted medRxiv a license to display the preprint in perpetuity.

It is made available under a CC-BY 4.0 International license .

11) Ai T, Yang Z, Hou H, Zhan C, Chen C, Lv W, Tao Q, Sun Z, Xia L. Correlation of Chest CT and RT-PCR Testing in Coronavirus Disease 2019 (COVID-19) in China: A Report of 1014 Cases. Radiology. 2020 Feb 26:200642. doi:10.1148/radiol.2020200642. [Epub ahead of print] PubMed PMID: 32101510.

12) Zhao S, Musa SS, Lin Q, Ran J, Yang G, Wang W, Lou Y, Yang L, Gao D, He D,Wang MH. Estimating the Unreported Number of Novel Coronavirus (2019-nCoV) Cases in China in the First Half of January 2020: A Data-Driven Modelling Analysis of the Early Outbreak. J Clin Med. 2020 Feb 1;9(2). pii: E388. doi:10.3390/jcm9020388. PubMed PMID: 32024089; PubMed Central PMCID: PMC7074332.

13) Wu JT, Leung K, Leung GM. Nowcasting and forecasting the potential domestic and international spread of the 2019-nCoV outbreak originating in Wuhan, China: a modelling study. Lancet. 2020 Feb 29;395(10225):689-697. doi:10.1016/S0140-6736(20)30260-9. Epub 2020 Jan 31. Erratum in: Lancet. 2020 Feb 4;.: PubMed PMID: 32014114.

14) Li $Q$, Guan $X$, Wu P, Wang $X$, Zhou L, Tong $Y$, Ren R, Leung KSM, Lau EHY, Wong JY, Xing $X$, Xiang N, Wu Y, Li C, Chen Q, Li D, Liu T, Zhao J, Liu M, Tu W, Chen C, Jin L, Yang R, Wang Q, Zhou S, Wang R, Liu H, Luo Y, Liu Y, Shao G, Li H, Tao Z, Yang Y, Deng Z, Liu B, Ma Z, Zhang Y, Shi G, Lam TTY, Wu JT, Gao GF, Cowling BJ, Yang B, Leung GM, Feng Z. Early Transmission Dynamics in Wuhan, China, of Novel Coronavirus-Infected Pneumonia. N Engl J Med. 2020 Mar 26;382(13):1199-1207. doi: 10.1056/NEJMoa2001316. Epub 2020 Jan 29. PubMed PMID: 31995857.

15) Borges do Nascimento IJ, Cacic N, Abdulazeem HM, von Groote TC, Jayarajah U, Weerasekara I, Esfahani MA, Civile VT, Marusic A, Jeroncic A, Carvas Junior N, Pericic TP, 
medRxiv preprint doi: https://doi.org/10.1101/2020.04.06.20054239; this version posted April 11, 2020. The copyright holder for this preprint (which was not certified by peer review) is the author/funder, who has granted medRxiv a license to display the preprint in perpetuity.

It is made available under a CC-BY 4.0 International license .

Zakarija-Grkovic I, Meirelles Guimarães SM, Luigi Bragazzi N, Bjorklund M, Sofi-Mahmudi A, Altujjar M, Tian M, Arcani DMC, O'Mathúna DP, Marcolino MS. Novel Coronavirus Infection (COVID-19) in Humans: A Scoping Review and Meta-Analysis. J Clin Med. 2020 Mar 30;9(4). pii: E941. doi:10.3390/jcm9040941. Review. PubMed PMID: 32235486.

16) Wang J, Wang Z. Strengths, Weaknesses, Opportunities and Threats (SWOT) Analysis of China's Prevention and Control Strategy for the COVID-19 Epidemic. Int J Environ Res Public Health. 2020 Mar 26;17(7). pii: E2235. doi: 10.3390/ijerph17072235. Review. PubMed PMID: 32225019.

17) loannidis JPA. Coronavirus disease 2019: the harms of exaggerated information and nonevidence-based measures. Eur J Clin Invest. 2020 Mar 19:e13222. doi:10.1111/eci.13222. [Epub ahead of print] PubMed PMID: 32191341.

18) loannidis JPA. Coronavirus disease 2019: the harms of exaggerated information and nonevidence-based measures. Eur J Clin Invest. 2020 Mar 23:e13223. doi: 10.1111/eci.13223. [Epub ahead of print] PubMed PMID: 32202659.

19) Zhou WK, Wang AL, Xia F, Xiao YN, Tang SY. Effects of media reporting on mitigating spread of COVID-19 in the early phase of the outbreak. Math BiosciEng. 2020 Mar 10;17(3):26932707. doi: 10.3934/mbe.2020147. PubMed PMID:32233561.

20) Verity R, Okell LC, Dorigatti I, Winskill P, Whittaker C, Imai N,Cuomo-Dannenburg G, Thompson H, Walker PGT, Fu H, Dighe A, Griffin JT, Baguelin M, Bhatia S, Boonyasiri A, Cori A, Cucunubá Z, FitzJohn R, Gaythorpe K, Green W, Hamlet A, Hinsley W, Laydon D, NedjatiGilani G, Riley S, van Elsland S, Volz E, Wang H, Wang Y, Xi X, Donnelly CA, Ghani AC, 
medRxiv preprint doi: https://doi.org/10.1101/2020.04.06.20054239; this version posted April 11, 2020. The copyright holder for this preprint (which was not certified by peer review) is the author/funder, who has granted medRxiv a license to display the preprint in perpetuity.

It is made available under a CC-BY 4.0 International license .

Ferguson NM. Estimates of the severity of coronavirus disease 2019: a model-based analysis.

Lancet Infect Dis. 2020 Mar 30. pii: S1473-3099(20)30243-7. doi: 10.1016/S14733099(20)30243-7.[Epub ahead of print] PubMed PMID: 32240634.

21) Worldometer:

COVID-19

Coronavirus

Pandemic.

https://www.worldometers.info/coronavirus/ - Accessed on $4^{\text {th }}$ April 2020.

22) Korean Society of Infectious Diseases; Korean Society of Pediatric Infectious Diseases; Korean Society of Epidemiology; Korean Society for Antimicrobial Therapy; Korean Society for Healthcare-associated Infection Control and Prevention; Korea Centers for Disease Control and Prevention. Report on the Epidemiological Features of Coronavirus Disease 2019 (COVID-19) Outbreak in the Republic of Korea from January 19 to March 2, 2020. J Korean Med Sci. 2020 Mar 16;35(10):e112. doi: 10.3346/jkms.2020.35.e112. PubMed PMID: 32174069; PubMed Central PMCID: PMC7073313.

23) Choi SC, Ki M. Estimating the reproductive number and the outbreak size of Novel Coronavirus disease (COVID-19) using mathematical model in Republic of Korea. Epidemiol Health. 2020 Mar 12:e2020011. doi: 10.4178/epih.e2020011. [Epub ahead of print] PubMed PMID: 32164053.

24) Her M. How is COVID-19 affecting South Korea? What is our current strategy? Disaster Med Public Health Prep. 2020 Apr 3:1-7. doi: 10.1017/dmp.2020.69. [Epub ahead of print] PubMed PMID: 32241325.

25) SARS-CoV-2 (COVID-19) Testing: Status Update 04 April 2020 9:00 PM IST. Indian Council of Medical Research. 
medRxiv preprint doi: https://doi.org/10.1101/2020.04.06.20054239; this version posted April 11, 2020. The copyright holder for this preprint (which was not certified by peer review) is the author/funder, who has granted medRxiv a license to display the preprint in perpetuity.

It is made available under a CC-BY 4.0 International license.

https://icmr.nic.in/sites/default/files/whats new/ICMR testing update 04April 9PM IST.p

df - Accessed on 4th April 2020

26) Brown IH. History and epidemiology of Swine influenza in Europe. Curr Top Microbiol Immunol. 2013;370:133-46. doi: 10.1007/82_2011_194. Review. PubMed PMID: 22234411.

27) Plans-Rubió $P$. The vaccination coverage required to establish herd immunity against influenza viruses. Prev Med. 2012;55(1):72-77. doi:10.1016/j.ypmed.2012.02.015

28) Francis ME, King ML, Kelvin AA. Back to the Future for Influenza Preimmunity-Looking Back at Influenza Virus History to Infer the Outcome of Future Infections. Viruses. 2019;11(2):122. Published 2019 Jan 30. doi:10.3390/v1102012

29) Katriel G, Stone L. Pandemic dynamics and the breakdown of herd immunity. PLoS One. 2010;5(3):e9565. Published 2010 Mar 15. doi:10.1371/journal.pone.0009565

30) Krammer F, Smith GJD, Fouchier RAM, et al. Influenza. Nat Rev Dis Primers. 2018;4(1):3. Published 2018 Jun 28. doi:10.1038/s41572-018-0002-y 
Table 1: COVID-19 Data Obtained on 4/4/2020 at 0900 BST - Wordometer Coronavirus Statistics

\begin{tabular}{|c|c|c|c|c|c|c|}
\hline Country & Cases & Deaths & Cases/million & $\begin{array}{c}\text { Deaths/millio } \\
\text { n }\end{array}$ & Tests & Tests/million \\
\hline USA & 277,475 & 7,402 & 838 & 22 & $1,355,091$ & 4,094 \\
\hline Italy & 119,827 & 14,681 & 1,982 & 243 & 619,849 & 10.252 \\
\hline Spain & 119,199 & 11,198 & 2,549 & 240 & 355,000 & 7,593 \\
\hline Germany & 91,159 & 1,275 & 1,088 & 15 & 918,460 & 10,962 \\
\hline France & 82,165 & 6.507 & 1.259 & 100 & 224.254 & 3,436 \\
\hline Iran & 53,183 & 3294 & 633 & 39 & 80,000 & 952 \\
\hline UK & 38,168 & 3.605 & 562 & 53 & 173,784 & 2,560 \\
\hline Turkey & 20,921 & 425 & 248 & 5 & 141,716 & 1,680 \\
\hline Switzerland & 19,606 & 591 & 2,265 & 68 & 145,780 & 16,844 \\
\hline Belgium & 16,770 & 1,143 & 1,447 & 99 & 62,867 & 5,424 \\
\hline Netherlands & 15,723 & 1,487 & 918 & 87 & 75,415 & 4,401 \\
\hline Canada & 12,549 & 208 & 332 & 6 & 302,745 & 8,021 \\
\hline Austria & 11,525 & 168 & 1.280 & 19 & 98,343 & 10,919 \\
\hline S. Korea & 10,156 & 177 & 198 & 3 & 455,032 & 8,875 \\
\hline Portugal & 9.886 & 246 & 970 & 24 & 52.086 & 5,108 \\
\hline Brazil & 9,216 & 365 & 43 & 2 & 54,824 & 258 \\
\hline Israel & 7,428 & 40 & 858 & 5 & 90,394 & 10,443 \\
\hline Sweden & 6,131 & 358 & 607 & 35 & 36,900 & 3,654 \\
\hline Australia & 5,550 & 30 & 218 & 1 & 285,675 & 11,203 \\
\hline Norway & 5,370 & 59 & 991 & 11 & 101.986 & 18,812 \\
\hline Ireland & 4,273 & 120 & 865 & 24 & 30,213 & 6,119 \\
\hline Czechia & 4,190 & 53 & 391 & 5 & 67,281 & 6,283 \\
\hline Russia & 4,149 & 34 & 28 & 0.2 & 575,000 & 3.940 \\
\hline Denmark & 3,757 & 139 & 649 & 24 & 40,863 & 7,055 \\
\hline Chile & 3,737 & 22 & 195 & 1 & 35,142 & 1.838 \\
\hline Poland & 3,383 & 71 & 89 & 2 & 66,938 & 1,769 \\
\hline Ecuador & 3,368 & 145 & 191 & 8 & 10,317 & 585 \\
\hline Malaysia & 3,333 & 53 & 103 & 2 & 47,723 & 1,474 \\
\hline Romania & 3,183 & 133 & 165 & 7 & 31.657 & 1,646 \\
\hline India & 3,082 & 86 & 2 & 0.06 & 116,608 & 84 \\
\hline Philippines & 3,018 & 136 & 28 & 1 & 5,265 & 48 \\
\hline Japan & 2,935 & 69 & 23 & 0.5 & 39,446 & 312 \\
\hline Pakistan & 2,708 & 40 & 12 & 0.2 & 30,308 & 137 \\
\hline Luxembourg & 2,612 & 31 & 4,173 & 50 & 21,463 & 34,287 \\
\hline Thailand & 2.067 & 20 & 30 & 0.3 & 23,669 & -339 \\
\hline Indonesia & 1986 & 181 & 7 & 0.7 & 7,193 & 26 \\
\hline Mexico & 1,688 & 60 & 13 & 0.5 & 15,668 & 122 \\
\hline Panama & 1,673 & 41 & 388 & 10 & 7,333 & 1,700 \\
\hline Finland & 1,615 & 20 & 291 & 4 & 26.500 & 4,783 \\
\hline Greece & 1.613 & 63 & 155 & 6 & 22,437 & 2,153 \\
\hline Peru & 1,595 & 61 & 48 & 2 & 16,518 & 501 \\
\hline South Africa & 1,505 & 9 & 25 & 0.2 & 50,361 & 849 \\
\hline $\begin{array}{l}\text { Dominican } \\
\text { Republic }\end{array}$ & 1,488 & 68 & 137 & 6 & 4,200 & 387 \\
\hline Serbia & $1 / 476$ & 39 & 169 & 4 & 5,756 & 659 \\
\hline Iceland & 1,364 & 4 & 3,997 & 12 & 22,195 & 65,042 \\
\hline Argentina & 1,353 & 42 & 30 & 0.9 & 7,385 & 163 \\
\hline Colombia & 1,267 & 25 & 25 & 0.5 & 21.202 & 417 \\
\hline UAE & 1.264 & 9 & 128 & 0.9 & 220,000 & 22.244 \\
\hline Algeria & 1,171 & 105 & 27 & 2 & 3,359 & 77 \\
\hline Singapore & 1,114 & 6 & 190 & 1 & 39,000 & 6,666 \\
\hline
\end{tabular}


Table 2: Highest COVID-19 testing rates according to tests per diagnosed case

\begin{tabular}{|c|c|c|c|c|c|c|}
\hline Country & $\begin{array}{l}\text { Tests per } \\
\text { positive } \\
\text { case }\end{array}$ & $\begin{array}{l}\text { Case fatality } \\
\text { rate } \%\end{array}$ & $\begin{array}{l}\text { Cases per } \\
\text { test rate } \%\end{array}$ & $\begin{array}{l}\text { Deaths per } \\
\text { test rate } \%\end{array}$ & $\begin{array}{l}\text { Population } \\
\text { (millions) }\end{array}$ & $\begin{array}{l}\% \text { of whole } \\
\text { population tested }\end{array}$ \\
\hline UAE & 174.05 & $5 \quad 0.71$ & 0.57 & 0.004 & 9.88 & 2.23 \\
\hline Russia & 138.59 & 0.82 & 0.72 & 0.01 & 148.18 & 0.39 \\
\hline Australia & 51.47 & 0.54 & 1.94 & 0.01 & 25.46 & 1.12 \\
\hline S. Korea & 44.80 & 1.74 & 2.23 & 0.04 & 51.29 & 0.89 \\
\hline India & 37.84 & 2.79 & 2.64 & 0.07 & 1541.00 & 0.01 \\
\hline Singapore & 35.01 & 0.54 & 2.86 & 0.02 & 5.86 & 0.67 \\
\hline South Africa & 33.46 & 0.60 & 2.99 & 0.02 & 60.20 & 0.08 \\
\hline Canada & 24.13 & 1.66 & 4.15 & 0.07 & 37.80 & 0.80 \\
\hline Poland & 19.79 & 2.10 & 5.05 & 0.11 & 38.01 & 0.18 \\
\hline Norway & 18.99 & 1.10 & 5.27 & 0.06 & 5.42 & 1.88 \\
\hline Colombia & 16.73 & 1.97 & 5.98 & 0.12 & 50.68 & 0.04 \\
\hline Finland & 16.41 & 1.24 & 6.09 & 0.08 & 5.55 & 0.48 \\
\hline Iceland & 16.27 & 0.29 & 6.15 & 0.02 & 0.34 & 6.50 \\
\hline Czechia & 16.06 & 1.26 & 6.23 & 0.08 & 10.72 & 0.63 \\
\hline Malaysia & 14.32 & 1.59 & 6.98 & 0.11 & 32.36 & 0.15 \\
\hline Greece & 13.91 & 3.91 & 7.19 & 0.28 & 10.41 & 0.22 \\
\hline Japan & 13.44 & 2.35 & 7.44 & 0.17 & 127.61 & 0.03 \\
\hline Israel & 12.17 & 0.54 & 8.22 & 0.04 & 8.66 & 1.04 \\
\hline Thailand & 11.45 & 0.97 & 8.73 & 0.08 & 68.90 & 0.03 \\
\hline Pakistan & 11.19 & 1.48 & 8.93 & 0.13 & 225.67 & 0.01 \\
\hline Denmark & 10.88 & 3.70 & 9.19 & 0.34 & 5.79 & 0.71 \\
\hline Peru & 10.36 & 3.82 & 9.66 & 0.37 & 33.23 & 0.05 \\
\hline Germany & 10.08 & 1.40 & 9.93 & 0.14 & 83.79 & 1.10 \\
\hline Romania & 9.95 & 4.18 & 10.05 & 0.42 & 19.29 & 0.16 \\
\hline Chile & 9.40 & 0.59 & 10.63 & 0.06 & 19.16 & 0.18 \\
\hline Mexico & 9.28 & 3.55 & 10.77 & 0.38 & 129.85 & 0.01 \\
\hline Austria & 8.53 & 1.46 & 11.72 & 0.17 & 9.00 & 1.09 \\
\hline Luxembourg & 8.22 & 1.19 & 12.17 & 0.14 & 0.63 & 3.43 \\
\hline Switzerland & 7.44 & 3.01 & 13.45 & 0.41 & 8.66 & 1.68 \\
\hline Ireland & 7.07 & 2.81 & 14.14 & 0.40 & 4.94 & 0.61 \\
\hline Turkey & 6.77 & 2.03 & 14.76 & 0.30 & 84.36 & 0.17 \\
\hline Sweden & 6.02 & 5.84 & 16.62 & 0.97 & 10.10 & 0.37 \\
\hline Brazil & 5.95 & 3.96 & 16.81 & 0.67 & 214.33 & 0.03 \\
\hline Argentina & 5.46 & 3.10 & 18.32 & 0.57 & 45.10 & 0.02 \\
\hline Portugal & 5.27 & 2.49 & 18.98 & 0.47 & 10.19 & 0.51 \\
\hline Italy & 5.17 & 12.25 & 19.33 & 2.37 & 60.46 & 1.03 \\
\hline USA & 4.88 & 2.67 & 20.48 & 0.55 & 331.12 & 0.41 \\
\hline Netherlands & 4.80 & 9.46 & 20.85 & 1.97 & 17.13 & 0.44 \\
\hline UK & 4.55 & 9.45 & 21.96 & 2.07 & 67.91 & 0.26 \\
\hline Panama & 4.38 & 2.45 & 22.81 & 0.56 & 4.31 & 0.17 \\
\hline Serbia & 3.90 & 2.64 & 25.64 & 0.68 & 8.73 & 0.07 \\
\hline Belgium & 3.75 & 6.82 & 26.68 & 1.82 & 11.59 & 0.54 \\
\hline Indonesia & 3.62 & 9.11 & 27.61 & 2.52 & 283.71 & 0.00 \\
\hline Ecuador & 3.06 & 4.31 & 32.65 & 1.41 & 17.63 & 0.06 \\
\hline Spain & 2.98 & 9.39 & 33.58 & 3.15 & 46.76 & 0.76 \\
\hline Algeria & 2.87 & 8.97 & 34.86 & 3.13 & 43.37 & 0.01 \\
\hline \multicolumn{7}{|l|}{ Dominican } \\
\hline Republic & 2.82 & 4.57 & 35.43 & 1.62 & 10.86 & 0.04 \\
\hline France & 2.73 & 7.92 & 36.64 & 2.90 & 65.26 & 0.34 \\
\hline Philippines & 1.74 & 4.51 & 57.32 & 2.58 & 107.79 & 0.00 \\
\hline Iran & 1.50 & 6.19 & 66.48 & 4.12 & 84.02 & 0.10 \\
\hline
\end{tabular}


Table 3: Highest projected population level COVID-19 deaths according to rate of death per test for each individual country on 4/4/20

\begin{tabular}{|c|c|c|c|c|}
\hline Country & $\begin{array}{l}\text { Population } \\
\text { (millions) }\end{array}$ & $\begin{array}{l}\% \text { of whole } \\
\text { population tested }\end{array}$ & $\begin{array}{l}\text { Extrapolated cases per } \\
\text { d population (millions) }\end{array}$ & $\begin{array}{l}\text { Extrapolated deaths } \\
\text { per population }\end{array}$ \\
\hline Indonesia & 283.71 & $1 \quad 0.003$ & $3 \quad 78.33$ & 7139203 \\
\hline Iran & 84.02 & 0.10 & 55.85 & 3459416 \\
\hline Philippines & 107.79 & 0.00 & 61.78 & 2784208 \\
\hline France & 65.26 & 0.34 & 23.91 & 1893659 \\
\hline USA & 331.12 & 0.41 & 67.80 & 1808675 \\
\hline Spain & 46.76 & 0.76 & 15.70 & 1475078 \\
\hline Italy & 60.46 & 1.03 & 11.69 & 1431927 \\
\hline Brazil & 214.33 & 0.03 & 36.03 & 1426909 \\
\hline UK & 67.91 & 0.26 & 14.92 & 1408830 \\
\hline Algeria & 43.37 & 0.01 & 15.12 & 1355728 \\
\hline India & 1541.00 & 0.01 & 40.73 & 1136509 \\
\hline Mexico & 129.85 & 0.01 & 13.99 & 497241 \\
\hline Netherlands & 17.13 & 0.44 & 3.57 & 337712 \\
\hline Pakistan & 225.67 & 0.01 & 20.16 & 297831 \\
\hline Argentina & 45.10 & 0.02 & 8.26 & 256493 \\
\hline Turkey & 84.36 & 0.17 & 12.45 & 252989 \\
\hline Ecuador & 17.63 & 0.06 & 5.76 & 247830 \\
\hline Japan & 127.61 & 0.03 & 9.49 & 223217 \\
\hline Belgium & 11.59 & 0.54 & 3.09 & 210711 \\
\hline \multicolumn{5}{|l|}{ Dominican } \\
\hline Republic & 10.86 & 0.04 & 3.85 & 175850 \\
\hline Peru & 33.23 & 0.05 & 3.21 & 122713 \\
\hline Germany & 83.79 & 1.10 & 8.32 & 116311 \\
\hline Sweden & 10.10 & 0.37 & 1.68 & 97994 \\
\hline Romania & 19.29 & 0.16 & 1.94 & 81047 \\
\hline Colombia & 50.68 & 0.04 & 3.03 & 59759 \\
\hline Serbia & 8.73 & 0.07 & 2.24 & 59176 \\
\hline Thailand & 68.90 & 0.03 & 6.02 & 58220 \\
\hline Portugal & 10.19 & 0.51 & 1.93 & 48135 \\
\hline Poland & 38.01 & 0.18 & 1.92 & 40318 \\
\hline Malaysia & 32.36 & 0.15 & 2.26 & 35937 \\
\hline Switzerland & 8.66 & 1.68 & 1.16 & 35092 \\
\hline Greece & 10.41 & 0.22 & 0.75 & 29220 \\
\hline Canada & 37.80 & 0.80 & 1.57 & 25969 \\
\hline Panama & 4.31 & 0.17 & 0.98 & 24108 \\
\hline S. Korea & 51.29 & 0.89 & 1.14 & 19952 \\
\hline Denmark & 5.79 & 0.71 & 0.53 & 19692 \\
\hline Ireland & 4.94 & 0.61 & 0.70 & 19620 \\
\hline Austria & 9.00 & 1.09 & 1.06 & 15381 \\
\hline Chile & 19.16 & 0.18 & 2.04 & 11997 \\
\hline South Africa & 60.20 & 0.08 & 1.80 & 10758 \\
\hline Russia & 148.18 & 0.39 & 1.07 & 8762 \\
\hline Czechia & 10.72 & 0.63 & 0.67 & 8442 \\
\hline Finland & 5.55 & 0.48 & 0.34 & 4189 \\
\hline Israel & 8.66 & 1.04 & 0.71 & 3831 \\
\hline Norway & 5.42 & 1.88 & 0.29 & 3135 \\
\hline Australia & 25.46 & 1.12 & 0.49 & 2674 \\
\hline Luxembourg & 0.63 & 3.43 & 0.08 & 904 \\
\hline Singapore & 5.86 & 0.67 & 0.17 & 902 \\
\hline UAE & 9.88 & 2.23 & 0.06 & 404 \\
\hline Iceland & 0.34 & 6.50 & 0.02 & 62 \\
\hline
\end{tabular}


Table 4: Highest projected population level COVID-19 deaths after adjustment according to countries who have tested at least 100000 tests

\begin{tabular}{|c|c|c|c|c|}
\hline Country & $\begin{array}{l}\text { Population } \\
\text { (millions) }\end{array}$ & $\begin{array}{l}\% \text { of population } \\
\text { tested }\end{array}$ & $\begin{array}{l}\text { Extrapolated cases per } \\
\text { population (millions) }\end{array}$ & $\begin{array}{l}\text { Extrapolated deaths } \\
\text { per population }\end{array}$ \\
\hline India & 1541.00 & 0.01 & 208.50 & 11865700 \\
\hline USA & 331.12 & 0.41 & 44.80 & 2549591 \\
\hline Indonesia & 283.71 & 0.003 & 38.39 & 2184600 \\
\hline Pakistan & 225.67 & 0.01 & 30.53 & 1737633 \\
\hline Brazil & 214.33 & 0.03 & 29.00 & 1650307 \\
\hline Russia & 148.18 & 0.39 & 20.05 & 1140975 \\
\hline Mexico & 129.85 & 0.01 & 17.57 & 999815 \\
\hline Japan & 127.61 & 0.03 & 17.27 & 982587 \\
\hline Philippines & 107.79 & 0.00 & 14.58 & 829950 \\
\hline Turkey & 84.36 & 0.17 & 11.41 & 649563 \\
\hline Iran & 84.02 & 0.10 & 11.37 & 646934 \\
\hline Germany & 83.79 & 1.10 & 11.34 & 645151 \\
\hline Thailand & 68.90 & 0.03 & 9.32 & 530530 \\
\hline UK & 67.91 & 0.26 & 9.19 & 522942 \\
\hline France & 65.26 & 0.34 & 8.83 & 502518 \\
\hline Italy & 60.46 & 1.03 & 8.18 & 465524 \\
\hline South Africa & 60.20 & 0.08 & 8.15 & 463540 \\
\hline S. Korea & 51.29 & 0.89 & 6.94 & 394956 \\
\hline Colombia & 50.68 & 0.04 & 6.86 & 390236 \\
\hline Spain & 46.76 & 0.76 & 6.33 & 360075 \\
\hline Argentina & 45.10 & 0.02 & 6.10 & 347270 \\
\hline Algeria & 43.37 & 0.01 & 5.87 & 333952 \\
\hline Poland & 38.01 & 0.18 & 5.14 & 292687 \\
\hline Canada & 37.80 & 0.80 & 5.11 & 291046 \\
\hline Peru & 33.23 & 0.05 & 4.50 & 255865 \\
\hline Malaysia & 32.36 & 0.15 & 4.38 & 249166 \\
\hline Australia & 25.46 & 1.12 & 3.44 & 196032 \\
\hline Romania & 19.29 & 0.16 & 2.61 & 148540 \\
\hline Chile & 19.16 & 0.18 & 2.59 & 147564 \\
\hline Ecuador & 17.63 & 0.06 & 2.39 & 135778 \\
\hline Netherlands & 17.13 & 0.44 & 2.32 & 131881 \\
\hline Belgium & 11.59 & 0.54 & 1.57 & 89239 \\
\hline \multicolumn{5}{|l|}{ Dominican } \\
\hline Republic & 10.86 & 0.04 & 1.47 & 83632 \\
\hline Czechia & 10.72 & 0.63 & 1.45 & 82514 \\
\hline Greece & 10.41 & 0.22 & 1.41 & 80130 \\
\hline Portugal & 10.19 & 0.51 & 1.38 & 78476 \\
\hline Sweden & 10.10 & 0.37 & 1.37 & 77774 \\
\hline UAE & 9.88 & 2.23 & 1.34 & 76038 \\
\hline Austria & 9.00 & 1.09 & 1.22 & 69330 \\
\hline Serbia & 8.73 & 0.07 & 1.18 & 67250 \\
\hline Israel & 8.66 & 1.04 & 1.17 & 66662 \\
\hline Switzerland & 8.66 & 1.68 & 1.17 & 66652 \\
\hline Singapore & 5.86 & 0.67 & 0.79 & 45146 \\
\hline Denmark & 5.79 & 0.71 & 0.78 & 44575 \\
\hline Finland & 5.55 & 0.48 & 0.75 & 42734 \\
\hline Norway & 5.42 & 1.88 & 0.73 & 41725 \\
\hline Ireland & 4.94 & 0.61 & 0.67 & 38037 \\
\hline Panama & 4.31 & 0.17 & 0.58 & 33201 \\
\hline Luxembourg & 0.63 & 3.43 & 0.08 & 4820 \\
\hline Iceland & 0.34 & 6.50 & 0.05 & 2628 \\
\hline
\end{tabular}


Table 5: Highest projected population level COVID-19 deaths after adjustment according to South Korea

\begin{tabular}{|c|c|c|c|c|}
\hline Country & $\begin{array}{l}\text { Population } \\
\text { (millions) }\end{array}$ & $\begin{array}{l}\% \text { of population } \\
\text { tested }\end{array}$ & $\begin{array}{l}\text { Extrapolated cases per } \\
\text { population (millions) }\end{array}$ & $\begin{array}{l}\text { Extrapolated deaths } \\
\text { per population }\end{array}$ \\
\hline India & 1541.00 & 0.01 & $1 \quad 34.36$ & 616400 \\
\hline USA & 331.12 & 0.41 & 7.38 & 132446 \\
\hline Indonesia & 283.71 & 0.003 & 6.33 & 113486 \\
\hline Pakistan & 225.67 & 0.01 & 5.03 & 90267 \\
\hline Brazil & 214.33 & 0.03 & 4.78 & 85730 \\
\hline Russia & 148.18 & 0.39 & 3.30 & 59271 \\
\hline Mexico & 129.85 & 0.01 & 2.90 & 51938 \\
\hline Japan & 127.61 & 0.03 & 2.85 & 51043 \\
\hline Philippines & 107.79 & 0.00 & 2.40 & 43114 \\
\hline Turkey & 84.36 & 0.17 & 1.88 & 33744 \\
\hline Iran & 84.02 & 0.10 & 1.87 & 33607 \\
\hline Germany & 83.79 & 1.10 & 1.87 & 33514 \\
\hline Thailand & 68.90 & 0.03 & 1.54 & 27560 \\
\hline UK & 67.91 & 0.26 & 1.51 & 27166 \\
\hline France & 65.26 & 0.34 & 1.46 & 26105 \\
\hline Italy & 60.46 & 1.03 & 1.35 & 24183 \\
\hline South Africa & 60.20 & 0.08 & 1.34 & 24080 \\
\hline S. Korea & 51.29 & 0.89 & 1.14 & 19952 \\
\hline Colombia & 50.68 & 0.04 & 1.13 & 20272 \\
\hline Spain & 46.76 & 0.76 & 1.04 & 18705 \\
\hline Argentina & 45.10 & 0.02 & 1.01 & 18040 \\
\hline Algeria & 43.37 & 0.01 & 0.97 & 17348 \\
\hline Poland & 38.01 & 0.18 & 0.85 & 15204 \\
\hline Canada & 37.80 & 0.80 & 0.84 & 15119 \\
\hline Peru & 33.23 & 0.05 & 0.74 & 13292 \\
\hline Malaysia & 32.36 & 0.15 & 0.72 & 12944 \\
\hline Australia & 25.46 & 1.12 & 0.57 & 10183 \\
\hline Romania & 19.29 & 0.16 & 0.43 & 7716 \\
\hline Chile & 19.16 & 0.18 & 0.43 & 7666 \\
\hline Ecuador & 17.63 & 0.06 & 0.39 & 7053 \\
\hline Netherlands & 17.13 & 0.44 & 0.38 & 6851 \\
\hline Belgium & 11.59 & 0.54 & 0.26 & 4636 \\
\hline \multicolumn{5}{|l|}{ Dominican } \\
\hline Republic & 10.86 & 0.04 & 0.24 & 4345 \\
\hline Czechia & 10.72 & 0.63 & 0.24 & 4286 \\
\hline Greece & 10.41 & 0.22 & 0.23 & 4163 \\
\hline Portugal & 10.19 & 0.51 & 0.23 & 4077 \\
\hline Sweden & 10.10 & 0.37 & 0.23 & 4040 \\
\hline UAE & 9.88 & 2.23 & 0.22 & 3950 \\
\hline Austria & 9.00 & 1.09 & 0.20 & 3602 \\
\hline Serbia & 8.73 & 0.07 & 0.19 & 3493 \\
\hline Israel & 8.66 & 1.04 & 0.19 & 3463 \\
\hline Switzerland & 8.66 & 1.68 & 0.19 & 3462 \\
\hline Singapore & 5.86 & 0.67 & 0.13 & 2345 \\
\hline Denmark & 5.79 & 0.71 & 0.13 & 2316 \\
\hline Finland & 5.55 & 0.48 & 0.12 & 2220 \\
\hline Norway & 5.42 & 1.88 & 0.12 & 2168 \\
\hline Ireland & 4.94 & 0.61 & 0.11 & 1976 \\
\hline Panama & 4.31 & 0.17 & 0.10 & 1725 \\
\hline Luxembourg & 0.63 & 3.43 & 0.01 & 250 \\
\hline Iceland & 0.34 & 6.50 & 0.01 & 137 \\
\hline
\end{tabular}


Figure 1: Case fatality rates according to percentage of total population tested for countries who have tested at least $1 \%$ of the whole population excluding Italy

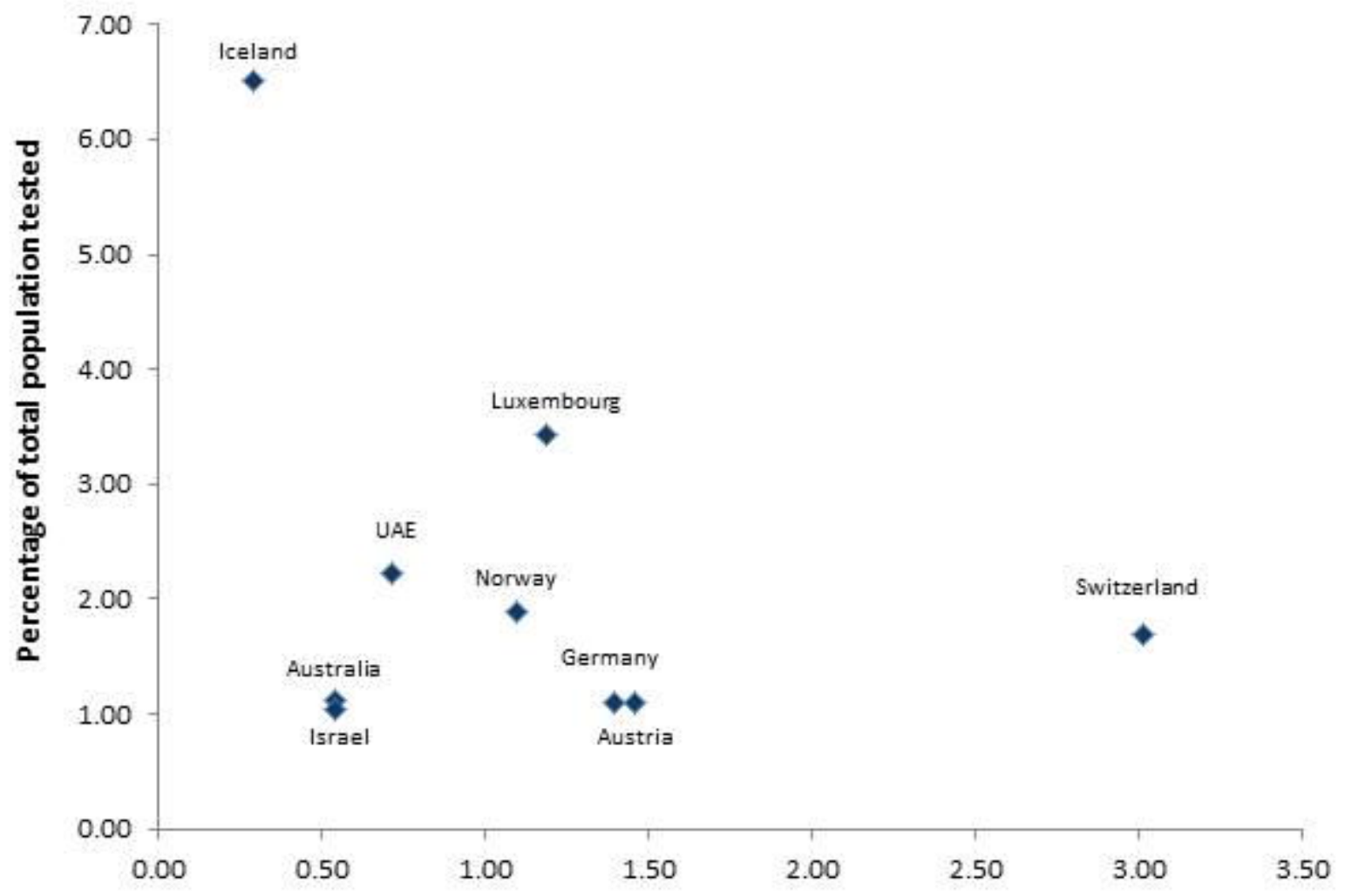

Case fatality rate as a percentage 